\title{
THE EU AGAINST THE DISINFORMATION OF CHINA AND RUSSIA DURING THE COVID-19. THE NEED FOR GREATER EUROPEAN NARRATIVE PROACTIVITY AT THE INTERNATIONAL LEVEL
}

\section{MIGUEL ANGEL BENEDICTO SOLSONA}

miguel.benedictosolsona@gmail.com

PhD in International Relations from the Complutense University of Madrid. He holds a degree in

Law from the University of Zaragoza, a degree in Information Sciences from the UCM and a degree in Political Science from the UNED. His areas of research are the European Union (foreign policy, security and defence and communication policy) and public diplomacy. He is a member of the research team of the project "Public diplomacy in Ibero-American megacities: communication strategies and soft power to influence global environmental legislation". As a lecturer, he also collaborates with the Universidad Europea de Madrid (Spain) and the Universidad Pontificia Comillas.

\begin{abstract}
Disinformation has been used by third countries to weaken the EU and its institutions; erode democracy and create social division. In the first wave of the Covid-19 pandemic, Russia and China have been in the spotlight for their influence operations in Europe. In the article we will analyse the concept of disinformation in the EU; external threats and the new role played by China and its use of social networks to improve its image and impose its alternative model of governance with sharp power techniques. Finally, the European strategy to defend itself against fake news will be evaluated and the need for the EU to be more proactive in creating frames that allow it to launch a narrative at international level and improve its public diplomacy.

\section{Keywords}

Disinformation, China, Russia, European Union sharp power, Covid-19

\section{How to cite this article}

Solsona, Miguel Ángel Benedicto. The EU against the disinformation of China and Russia during the COVID-19. The need for greater European narrative proactivity at the international level. Thematic dossier International Relations and Social Networks, July 2021. Consulted [online] at dat of last visit, https://doi.org/10.26619/1647-7251.DT21.6
\end{abstract}

Article received on January 5, 2021 and accepted for publication on March 2, 2021 


\title{
THE EU AGAINST THE DISINFORMATION OF CHINA AND RUSSIA DURING THE COVID-19. THE NEED FOR GREATER EUROPEAN NARRATIVE PROACTIVITY AT THE INTERNATIONAL LEVEL ${ }^{1}$
}

\author{
MIGUEL ÁNGEL BENEDICTO SOLSONA
}

\section{Introduction}

The European Union has been suffering from the phenomenon of disinformation since 2015. After the illegal annexation of Crimea by Russia, Moscow has not stopped using this type of tool to destabilize different European countries, especially during electoral campaigns, causing social polarization and a decrease in trust in institutions and democracy. $73 \%$ of European internet users were concerned about disinformation during election periods; $85 \%$ of those surveyed perceive fake news online as a problem in their country and $83 \%$ as a problem for democracy in general (Flash Eurobarometer 464, 2018).

To curb these threats, the EU put in place instruments to combat fake news with relative success during the European Parliament elections in May 2019. However, the Covid-19 pandemic has shown that the measures were not enough. Technology and social platforms change, attacks are increasingly sophisticated and aggressive. In addition, countries like China, although with different objectives than the Russians, as we will see, have also targeted the phenomenon of disinformation in Europe.

\section{Methodology and fieldwork}

This article examines as actors outside the EU, like Russia and China, have launched interference and misinformation processes during the pandemic. We have analyzed the reports of the EU External Action Service (EEAS) since March 2020 to see what the interference of the Kremlin and Beijing-controlled media has been. Due to the importance of social platforms, we have also reviewed the Hamilton 2.0 panel $^{2}$, a project of Alliance for Securing Democracy and the German Marshall Fund, which provides an analysis of 
the narratives and topics promoted by Russian, Chinese and Iranian officials on social media and media funded by those countries.

The novelty of the Chinese case in the use of disinformation in the EU has also led us to analyze the action of China's Foreign Ministry on twitter from February to April 2020, the toughest months of the pandemic in the EU. For the fieldwork we have collected 266 tweets from the official account of the Chinese Foreign Ministry uploaded between February and April 2020, which is when the pandemic hit hardest in Europe during the first wave. We have analyzed how many tweets have been written in relation to Covid19 during those months, which countries have been most cited by that ministry within and outside the EU, which institutions are the most named and the type of coronavirus information that China has uploaded on twitter.

Likewise, the measures that the EU has put in place against disinformation, before and after the pandemic, are analyzed.

\section{Theoretical considerations about Soft power and Sharp power}

During the coronavirus crisis, European institutions suffered attacks from Russia and China. Moscow has been using disinformation campaigns for years in various EU countries with the aim of weakening its institutions, creating social division and eroding democracy. In contrast, Beijing had not used such actions until the emergence of Covid-19 with the aim of presenting its own narrative on the origin of the pandemic, improving its image in the EU through mask diplomacy ${ }^{3}$, or supporting countries related to the New Silk Road ${ }^{4}$ (BRI).

Both countries have been equipped with instruments to implement coordinated actions aimed at democratic states to violate their institutions through political, economic, military, civil means or information related. Russia and China use soft power to attract foreign audiences, but under that guise are disruptive operations that can be described as sharp power; used by some countries to crack democratic systems such as the EU.

The concept of soft power is attributed to Joseph Nye (2004: 5) who defines it as a form of non-coercive power that has the effect of "getting others to want the outcomes you want" through the "ability of attraction, [which] leads to acquiescence."

The decline of the state monopoly for the benefit of shared sovereignty in economic and communicative matters raises the need to rethink traditional diplomacy. It does not seem possible to return to a closed international system monopolized by state activity, but rather a more open diplomacy, more mediated by the media, in which civil society plays an increasingly important role. Public diplomacy according to Nye (2008) "is an indispensable tool for promoting the soft power of a country". In this sense, Van Ham (2005: 47) explains that it is "used by states to turn hard power into the soft power of legitimacy, credibility, cultural superiority, and normative dominance. The wheels of hard

3 It is an attempt to improve China's image abroad as the country from which the virus had come through medical assistance or the shipment of sanitary supplies or masks by Beijing, donations from companies or Chinese communities abroad.

4 It is a geopolitical project that seeks to integrate Asia, Europe and Africa into a market with an intercontinental transport network. 
power alone can work smoothly with the soft power lubricant, of which public diplomacy is a key element."

However, when Russia or China use diplomacy to undermine the political system of another country, Walker and Ludwig (2017a) do not speak of soft but of sharp power. A concept that they coined in Foreign Affairs magazine as the use of manipulative diplomatic policies by one country to influence and undermine the political system of another country. According to Walker (2016) "authoritarian regimes exploit the opportunities that globalization provides and create an undemocratic toolkit". This includes NGOs controlled by governments, the use of investment and foreign aid and they use traditional and online media. They create an alternative model that reduces the political space of civil society by building an infrastructure, working together in existing or newly created international organizations, which allows them to challenge democracies and their values.

Walker and Ludwig argue that Moscow and Beijing's efforts in public diplomacy are not based on attraction or even persuasion, but on manipulation. Sharp power seeks to "penetrate or pierce" the political information and environments of the selected countries. It is a power that uses policies that help authoritarian regimes to coerce and manipulate opinions abroad. The corrosive effects of sharp power are evident in the spheres of culture, academia, the media and publications, sectors that are more vulnerable due to their financial insecurity (Hala, 2020). Open and accessible democracies like the EU are vulnerable to that sharp power.

China wants to play a more important role at the global level and to do this it promotes its ideas, rules and models of government through censorship or manipulation to undermine the integrity of independent institutions. According to Nye (2021) "China must realize that most of a country's soft power comes from its civil society rather than from its government." China's problem is that the actors involved in its public diplomacy depend on the control of the communist party (Walker, 2018). The repressive system of the Chinese government nullifies non-state actors and turns its soft power and public diplomacy into a sharp power that seeks to manipulate or coerce opinions abroad (Benedicto, 2020).

\section{Activities of Russia and China during the first wave of Covid-19}

COVID-19 has given rise to what the WHO calls an "infodemic ${ }^{5 "}$, which in the lockdown was aggravated by the massive use of social networks to access information. During the coronavirus crisis, the situation has become more complex with false information about the virus, attacks on ethnic or religious groups as the origin of the pandemic, consumer fraud, conspiracy theories, cybercrime and selective disinformation campaigns by of foreign or national agents who seek to undermine democracy and the credibility of the EU and national or regional authorities (European Commission, 2020a).

5 Excess information on a matter, but also disinformation or conspiracy theories that create confusion and mistrust and prevent an effective response to the problem. https://www.who.int/docs/defaultsource/coronaviruse/situation-reports/20200305-sitrep-45-covid-19.pdf?sfvrsn=ed2ba78b 4 
In this article we focus on the challenge that third countries, such as Russia and China, have undertaken with disinformation campaigns about COVID-19 in the EU and its neighboring countries, with which they seek to undermine the democratic debate and exacerbate social polarization, thereby improving their own image in relation to the pandemic. Moscow and Beijing took advantage of the fact that the EU's initial response to the coronavirus was late and unsupportive. The ban on exporting medical supplies by France or Germany to a needy Italy was a serious blow to the image of the EU. China and Russia deployed a strategy of public diplomacy, with the shipment of medical supplies. The EU, which does not have health competencies, saw how China with "mask diplomacy" filled the gap in European leadership and coordination; and got Italy, Spain or Serbia to thank and even ask Beijing for help.

The European Commission reacted later by opening transport corridors so that medical supplies could reach any EU country that needed them. EU also offered assistance to candidate countries in the Western Balkans, but the initial image of lack of solidarity had already been set.

\subsection{EEAS reports on Moscow and Beijing activity}

In the first EEAS report (2020a) the attacks on Brussels were highlighted due to the low support for its Member States; while countries like Italy were assisted by China or the Schengen area was broken. Russia's objective was to generate mistrust in authorities and national and European health systems, international institutions and scientific experts.

For its part, China spread information about the great work done by Xi Jinping to contain the coronavirus; while the West and the United States worked too slowly and are now in total disarray from the virus.

In the second report of the EEAS (2020 b) of the end of April, it is concluded that both Russia and China, to a lesser extent, have disseminated conspiracy and disinformation theories directed both to the public of the European Union and of neighboring countries.

Russian state media carry out a coordinated campaign with the dual aim of undermining the European Union and its response to the crisis, and of sowing confusion about the origins and health consequences of COVID-19, even if it contradicts WHO official guidelines and social media content policies.

From mid-February to the end of March 2020, Beijing was characterized by questioning the origin of the virus, restricting references to Wuhan or sowing doubts by attributing the start of the virus to the American military; and highlight the role of China as a world leader in the response to coronavirus led by Xi Jinping (Recorded Future, 2020). According to the Daily Telegraph (2020), some Chinese state media circumvented the rules on political advertising on social media and launched campaigns praising China's handling of the virus and attacking the United States.

China diverted any possible responsibility for the outbreak of the pandemic and did not stop publicizing the bilateral assistance, which it provides to some European countries, highlighting that Beijing has been more helpful than the European Union in the fight against the pandemic. The strategy worked in Italy where $52 \%$ of respondents by polling 
company SWG in March considered China a friendly country of Italy, a $42 \%$ increase from January 2020. However, the percentage of respondents who trusted the European Union fell to $27 \%$ in March 2020 from 42\% in September 2019. As for China's strategic partners outside Europe, $36 \%$ believe that China should be looked at compared to $30 \%$ that they think they should look at the United States.

Figure 1. "International alliances: China recovers credit among Italians and is now preferred to the United States"

\section{Alleanze internazionali: la Cina recupera credito tra gli italiani e ora è preferita agli Stati Uniti}
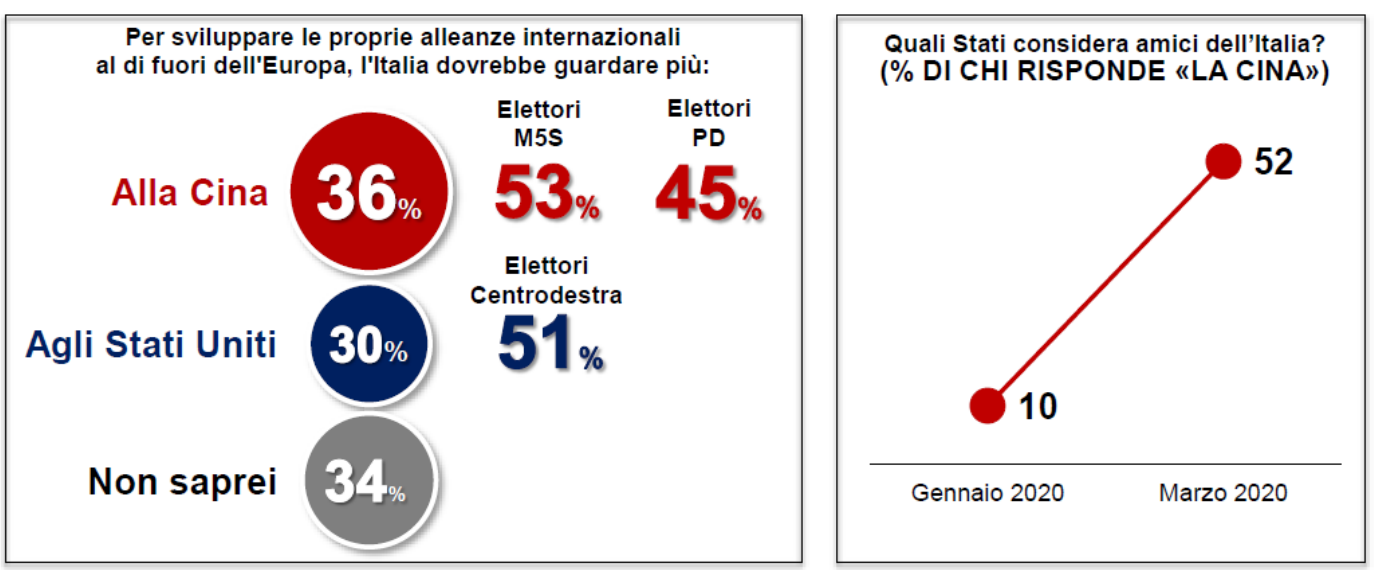

SWG

NOTA INFORMATIVA: valori espressi in \%. Date di esecuzione: 1 - 3 aprile 2020. Metodo di rilevazione: sondaggio CATI-CAMI-CAWI su un campione rappresentativo nazionale di 800 soggetti maggiorenni.

Fuente: Magazine Formiche.

Formiche magazine (2020) detected a coordinated Twitter bot operation in Italy to broaden the reach of messages from the Chinese embassy praising their country and to attack the European Union. Also countries in the Eastern neighborhood of the EU, on the southern shore of the Mediterranean and the Western Balkans, receive information showing Europe divided or weak in dealing with the crisis effectively (EEAS, 2020 b).

In the third EEAS report (2020c) in May, "Russian controlled television channels promoted disinformation narratives about the collapse of Western values and China has tried to control the narrative about COVID-19 and deflect any criticism to be portrayed as a responsible and transparent actor during the pandemic and a role model for other countries."

According to Freedom House (2020), since March 2020, coordinated and covert attempts have been detected by actors linked to China to manipulate information about Covid-19 in countries such as Italy or Serbia, among others, with content in local languages. Beijing increasingly adopts the Russian style and no longer only censors the criticism it 
receives, but also starts to sow doubts and use conspiracy theories with a strong proactivity of officials on social networks called wolf warrior diplomacy. ${ }^{6}$

In the fourth report of the EEAS (2020d) of December 2020, disinformation decreases and focuses on vaccines. Russia praises Sputnik $V$ with a triumphant speech and China highlights its response to Covid-19 as a commitment to multilateralism and the rapid reopening of its economy.

\subsection{Chinese Foreign Ministry twitter analysis}

The dissemination of messages on these platforms aims to ensure China's discursive power in the world, which is one of the most important goals of increasing its soft power (Zhao, 2020). According to the analysis, which we have carried out on the tweets in English uploaded in the account of the Chinese Foreign Ministry, during the first three months of the first wave of the pandemic in the EU, $78 \%$ had to do with Covid-19. The first month was the one with the most intensity on the social network, especially to try to hide the origin of the virus and divert attention with conspiracy theories and accusations of racism. Beijing also appreciated the solidarity of countries such as Pakistan, Serbia and ASEAN partners.

In February, the country most cited on the Twitter of the Foreign Ministry was Pakistan and in Europe, Italy was the first and curiously, small countries like Serbia and Montenegro ranked fourth and fifth. They all have something in common: their membership in the Chinese geopolitical project of the New Silk Road. As for the most cited institution, it is undoubtedly the WHO with which Beijing wants to demonstrate its commitment to multilateralism. In the early stages of the outbreak, official Chinese messages focused on solidarity, human interest stories and Beijing's efforts to respond to the crisis such as the video of the construction of the Wuhan hospital.

But in March, as the virus spread rapidly to Europe and the United States, that focus shifted, criticizing the Trump administration's handling of the virus and highlighting the chaos of democratic systems. Beijing began to question the origin of the virus in Wuhan. China began to designate the American military as the inoculators of Covid-19; and to highlight the role of China as a world leader in the response to the coronavirus and underline that the Chinese supply chain remains active. In addition, Beijing did not stop propaganda about his assistance to European countries such as Italy and Serbia, while highlighting the inaction of Brussels.

In April, the number of tweets rose and the most cited country was the United States, which is accused of manufacturing the virus in a laboratory in the former USSR. This conspiracy theory about American biological laboratories was tweeted on more than one occasion by the official account of the Chinese Foreign Ministry and covered by its official media.

$6 \quad$ It is characterized by the use of confrontational rhetoric by Chinese diplomats by denouncing criticism of China and being combative in interviews and on social media. 
Table 1. China on twitter

\begin{tabular}{|c|c|c|c|}
\hline Months & February 2020 & March 2020 & April 2020 \\
\hline $\begin{array}{l}\text { Total tweets } \\
\text { MFA China }\end{array}$ & 125 & 63 & 78 \\
\hline $\begin{array}{l}\text { Tweets about } \\
\text { the Covid-19 }\end{array}$ & 103 & 42 & 63 \\
\hline $\begin{array}{l}\text { Most } \\
\text { country } \\
\text { outside } \\
\text { Europe }\end{array}$ & Pakistan 11 & USA 7 & USA 8 \\
\hline $\begin{array}{l}\text { Most cited } \\
\text { European } \\
\text { country }\end{array}$ & $\begin{array}{l}\text { Italy } 4 \\
\text { France } 2 \\
\text { Germany } 3 \\
\text { Serbia } 2 \\
\text { Montenegro } 1\end{array}$ & $\begin{array}{l}\text { Italy } 2 \\
\text { Serbia } 2\end{array}$ & France 2 \\
\hline $\begin{array}{l}\text { Most cited } \\
\text { institution }\end{array}$ & WHO 10 & WHO 7 & $\begin{array}{l}\text { WHO } 8 \\
\text { ASEAN } 2\end{array}$ \\
\hline $\begin{array}{l}\text { Issues that } \\
\text { most concern } \\
\text { China related } \\
\text { to COVID }\end{array}$ & $\begin{array}{l}\text {-Complaints about } \\
\text { information about } \\
\text { the origin of the virus } \\
\text { in a Chinese } \\
\text { laboratory, racism } \\
\text { and conspiracy } \\
\text { theories. } \\
\text {-Thank you for the } \\
\text { solidarity of Pakistan, } \\
\text { Serbia and ASEAN. } \\
\text {-Video of the } \\
\text { construction of } \\
\text { Wuhan Hospital } \\
\text {-Solidarity with } \\
\text { Japan and South } \\
\text { Korea. }\end{array}$ & $\begin{array}{l}\text {-Don't call it } \\
\text { Wuhan virus } \\
\text {-Support for } \\
\text { countries such } \\
\text { as Italy or } \\
\text { Serbia } \\
\text {-Chinese supply } \\
\text { chain operates } \\
\text { despite Covid }\end{array}$ & $\begin{array}{l}\text {-Laboratories of USA in the former } \\
\text { USSR as the source of the virus. } \\
\text {-Threat of not sending medical } \\
\text { equipment to Netherlands by changing } \\
\text { Taiwan's official name } \\
\text {-WHO experts rule out that the virus } \\
\text { comes from a Chinese laboratory. } \\
\text {-Criticism of the attempt to destabilize } \\
\text { the relationship between China and } \\
\text { Africa. } \\
\text {-Defense of the Director-General of } \\
\text { WHO for racist attacks. } \\
\text {-Tweets sending doctors, masks or } \\
\text { medical equipment to Pakistan, Serbia, } \\
\text { Nigeria Kazakhstan, USA, ASEAN; } \\
\text { Djibouti, Russia, Myanmar, Cambodia, } \\
\text { Bangladesh, and Taiwan. }\end{array}$ \\
\hline
\end{tabular}

Source: Own elaboration according to the official Twitter account of the Chinese Foreign Ministry

In addition, campaigns were launched praising China's management of the virus and attacking the United States. Beijing diverted its responsibility for managing the virus at the beginning of the pandemic and stressed that the WHO ruled out that it was created in a Chinese laboratory. Likewise, he did not stop tweeting information about the shipment of medical supplies, doctors and masks to different countries of the world, giving rise to the so-called mask diplomacy and improving his image in Italy or Serbia. 


\section{EU strategies against disinformation}

\subsection{Disinformation: a broader concept than fake news}

The phenomenon of disinformation in the EU goes beyond the term 'fake news' as is apparent from the report made for the European Commission by the High-Level Expert Group (HLEG), which defines disinformation "like all forms of false information, inaccurate or misleading designed, presented, edited or promoted to intentionally cause public harm or to profit" (European Commission, 2018 to p.3). Trolls and hackers use big data $^{7}$ and algorithms to identify each person's unique weaknesses and trends for producing stories consistent with them and help bots spread ${ }^{8}$ them. They use these stories to reinforce the prejudices of those who believe in it to exacerbate the cracks in society and pierce the democratic system from within. (Brahms, 2019).

\subsection{How to combat disinformation}

Russia has a budget of between 3 billion and 4 billion for disinformation measures (McCauley, 2016) and as Roig explains (2018) uses instruments such as Russian information agencies RT and Sputnik abroad. It controls almost all national televisions, uses the Internet Research Agency (IRA) to flood social media, and generates sophisticated and massive disinformation operations. Some 15,000 people work on these disinformation tasks (McCauley, 2016) and Sputnik and RT, providing stories to be spread through social media.

A study on information manipulation conducted by the French government (Vilmer et al., 2018) states that $80 \%$ of the European authorities consulted attribute interference in Europe to Russia but they also do so to other states (mainly China and Iran) and nonstate actors (jihadist groups, in particular ISIS). However, some academics have questioned this percentage on the basis that such volume is barely measurable "because there is no consensus on what exactly constitutes disinformation."

The cross-border dimension of disinformation has required a coordinated and long-term approach among EU Member States to meet this challenge. In 2015, the European institutions created the East Stratcom (Communication Strategy for the East) Group, a pioneer against fake news to assist candidate countries and partners in the EU's neighbourhood in their efforts to counter hostile propaganda and disinformation activities (European Parliament, 2019). The Working Group disseminates thousands of examples of Kremlin-friendly disinformation and studies the techniques and intentions of Russianorigin campaigns on daily basis.

The EU adopted in 2016 a Common Framework for combating hybrid threats underlining the threat posed by massive disinformation campaigns, which uses social media to control political narrative or to radicalize, recruit and represent indirect actors. It is an issue which falls within the scope of national security and defence and the main

Person who uses social media to distribute fake news or posts to destabilize and influence public opinion.

Computer programs that mimic human interaction and automatically disseminate disinformation campaigns on social media. 
responsibility lies with the Member States. However, common threats can attack crossborder networks or infrastructures and they are more effectively addressed with a coordinated response at European level (EuropeanParliament, 2016).

As part of the planned measures, the Hybrid Threat Fusion Cell was established at the EEAS in 2016 and one year after the European Centre for Combating Hybrid Threats was opened in Helsinki with the participation of 10 EU Member States, Norway and the US. The openness and collaboration between NATO and the EU were a sign that tensions with Russia over its campaigns of influence in the West could no longer be ignored.

The HLEG (European Commission, 2018a) conclusion report describes the harmful effects of disinformation due to increased institutional mistrust and increased social tensions, and the implications it could have for internal security if combined with cyberattacks or public policy making given its influence on public opinion. Disinformation could affect policies, social debates and behaviors in areas such as climate change, migration, public safety, health and finance; and can undermine confidence in science and empirical testing (European Commission, 2018b). In this document, it was pointed out that the platforms had barely taken measures against misinformation and it was doubted that they would protect their users well against the unauthorized use of their personal data by third parties.

In 2018, a Code of Practice against disinformation was launched, signed by platforms such as Facebook, Google, Twitter, Mozilla and Microsoft, which pledged to take action and the Commission to monitor its effectiveness on a regular basis. The European Commission also approved an Action Plan against disinformation, created a Rapid Alert System to have closer coordination between the EU and national authorities; and increased international cooperation with the G7 and NATO.

Before the European elections, the European Parliament (2019) approved a Report to sensitize the public opinion "about the disinformation campaigns of Russia, since they constitute the main source of fake news in Europe". The report's speaker (Fotyga, 2019) noted that "the dissemination of disinformation has become more sophisticated due to new tools (for example, private messaging applications, search engine optimization, manipulated sound or images) and more aggressive". The report condemned the actions of Russia, China, Iran and North Korea, which according to MEPs sought to undermine European democracies and the sovereignty of all Eastern European Partnership countries, as well as influence elections and support extremist movements. MEPs urged the EU to strengthen the East StratCom anti-propaganda group to combat attacks from Russia.

The measures adopted during the European elections helped to combat disinformation and preserve the integrity of the elections According to the European Commission Report (2019) "the available evidence has not made it possible to determine the existence of a clear cross-border campaign of disinformation from external sources and specifically targeting the European elections." However, they revealed ongoing and sustained disinformation activity by Russian sources with the aim of discouraging electoral turnout and influencing voters' preferences. Thus, democratic legitimacy of the Union was questioned; controversial public debates were exploited on issues such as migration and sovereignty. "This confirms that the disinformation campaigns deployed by state and non-state actors pose a hybrid threat to the EU" (European Commission, 2019a). 
Cooperation with platforms improved, but not enough. "More than 600 Facebook groups and pages operating in France, Germany, Italy, the United Kingdom, Poland and Spain have spread disinformation and incitement to hatred or have used false profiles to artificially promote the content of the parties or sites they support." (Graham-Harrison, 2019). Complaints from researchers, fact-checkers and civil society also served to detect other cases of large-scale attempts to manipulate voter behavior in at least nine Member States (Avaaz, 2019).

However, the coronavirus crisis has once again put on the table that it is necessary to continue working to avoid disinformation, especially in relation to third countries, such as China and Russia that have launched influence operations, as is clear from the communication of June 2020 from the European Commission (2020a). To avoid these external interferences, the EU seeks international collaboration with the G7, NATO and WHO and a more active role in communicating locally, especially in the use of social networks.

In the public consultation carried out by the European Commission (2020b), $69 \%$ of those surveyed were in favour of some type of regulation on disinformation and $57 \%$ supported the option of following the Code of Practices on Disinformation and combining it with some type of legal measure. After the consultation, the Action Plan for European Democracy was presented with tougher measures to prevent foreign interference in EU electoral processes and disinformation. The purpose of the European Commission Plan (2020c), which will be implemented until the European elections of 2023, is to move from self-regulation to "co-regulation" in line with the next Digital Services Act. According to the document, it seeks to reduce the economic incentives to spread disinformation and impose sanctions, although it is not explained how they will be, to the actors involved in operations of influence and foreign interference". In the proposal made by the Commission on the new Digital Services Act, the mechanisms to eliminate illegal content are improved and greater public supervision of platforms is introduced.

\subsection{Creation of European frameworks}

The EU has a public sphere under construction in which when it comes to fighting fake news, it has opted for fact checking instead of creating alternative frameworks at the European level (Tuñon, Oleart and Bouza, 2019). The commitment to fact checkers is reactive because their strategy is to deny the falsehoods that circulate in the public sphere, and in doing so the effect of disinformation is amplified by reproducing the frames that are used to debate. If we apply the theory of framing, we realize the importance of proactivity in communication, especially when establishing discursive frameworks. Following Lakoff (2004), the repetition of the disinformation framework extends it into the incipient European public sphere rather than defeating it.

During the coronavirus crisis, Russia and China have been active in setting frameworks and have used sharp power to do so. However, the EU was unable to use its public diplomacy or proactive narratives to create alternative frameworks at the geopolitical level. The EU has provided more aid to its states than it has received from China, however, the perception of European citizens at the beginning of the crisis was the opposite. As French President Emmanuel Macron explained, the EU and its member states 
have been unable to display such mutual assistance in their public narratives (Mallet and Khalaf, 2020).

\section{Conclusions}

Russia continues with its disinformation campaigns in the EU with the aim of destabilizing, polarizing and diminishing the confidence of Europeans in its institutions and in democracy in order to avoid the enlargement of the EU and the Atlantic Alliance to its area of influence. A strategy that China has joined, especially since the first wave of the pandemic in Europe, to hide the origin of the virus and promote a positive image abroad and its governance model as opposed to Western democracy.

China saw in Italy and Spain or in the request for help from Serbia, its opportunity to turn around the global narrative on the coronavirus that placed Beijing as the origin, cover-up and accelerator of the pandemic and Covid-19 as the "Chernobyl" Chinese. Beijing turned the crisis into a geopolitical opportunity with a strong soft power campaign to fill the gap left by the US and the EU. Chinese officials have increased their presence on Western social media platforms. Thus, for example, the diplomatic corps uses Twitter more and more as a platform to influence world public opinion, with the paradox that it is blocked in China. Beijing has chosen to shape the global information environment beyond its borders. The proactivity of Chinese officials in social networks and foreign media points to a change in their foreign policy that is increasingly assertive as is their communication and public diplomacy, although it is full of sharp power.

China has opted for an international narrative that no longer passes only by censoring the criticism it receives, but by using disinformation and Russian-style conspiracy theories. Mask diplomacy has worked in the EU and in its neighborhood. In Italy, China's image improved at the beginning of the pandemic, and the inaction of Brussels served as Serbian President Alexander Vucik to ask Beijing for help. These examples demonstrate the need for the EU to strengthen and coordinate its strategic communication within and outside its territory to neutralize misinformation and stories such as its lack of solidarity during the pandemic. But it is not only necessary to strengthen strategic communication, but also to improve the public diplomacy of the EU delegations abroad in collaboration with the embassies of the 27 Member States. Internally, the offices of the European Parliament and Commission representations should also play a more active role in national debates at the media and social media level.

The EU should not only try to defend itself against third country operations, but it needs to be able to create alternative narrative frameworks at the geopolitical level as a road to combat disinformation in a weak and incipient European public sphere.

\section{References}

Avaaz (2019). Far right networks of deception. Avaaz investigation uncovers flood of disinformation, triggering shutdown of Facebook pages with over 500 million views ahead of EU elections. 22/05/2019. Avaaz Report. 
Benedicto, M. A. (2020). China y la Belt and Road Iniciative: un arma de doble filo (del Soft power al Sharp power) para transformar el mundo. In P. González del Miño (Coord.). El sistema internacional del siglo XXI (pp. 305-325). Valencia: Tirant Lo Blanch.

Brahms, Y. (2019). Philosophy of Post-Truth, Institute for National Security Studies. Tel Aviv: Tel Aviv University.

Dodds, I. (2020, April 5). China floods Facebook with undeclared coronavirus propaganda ads blaming Trump. Daily Telegraph. Available at: https://www.telegraph.co.uk/technology/2020/04/05/china-floods-facebook-instagramundeclared-coronavirus-propaganda/

European Commission (2018a). A multi-dimensional approach to disinformation. Report of the independent Highlevel Group on fake news and online disinformation. Luxembourg, Publication's office of the EU, March 2018.

European Commission (2018b). Communication on Tackling Online Disinformation. Bruselas, 26 April. Available at: https://eur-lex.europa.eu/legalcontent/EN/TXT/?uri=CELEX:52018DC0236

European Commission (2019). Informe sobre la aplicación del Plan de acción contra la desinformación 2019/12 final, 14 Junio. Available at: https://eur-lex.europa.eu/legalcontent/EN/ALL/?uri=comnat:JOIN 20190012 FIN

European Commission (2020a). La lucha contra la desinformación acerca de la COVID19: contrastando los datos. Bruselas, 10.6.2020. Available at: https://eurlex.europa.eu/legal-content/ES/TXT/HTML/?uri=CELEX:52020JC0008\&from=EN

European Commission (2020b). Report on the Public Consultation for the European Democracy Action Plan Available at: https://ec.europa.eu/info/sites/info/files/report edap public consultation final.pdf

European Commission (2020c). Plan de Acción para la Democracia Europea. Bruselas, 3.12.2020 COM/2020/790 final. Available at: https://eur-lex.europa.eu/legalcontent/ES/TXT/?uri=COM\%3A2020\%3A790\%3AFIN\&qid $=1607079662423$

European Parliament (2016). La comunicación estratégica de la Unión para contrarrestar la propaganda de terceros en su contra (2016/2030(INI). Available at: https://www.europarl.europa.eu/doceo/document/TA-8-2016-0441 ES.pdf?redirect

European Parliament (2019). Balance del seguimiento realizado por el SEAE dos años después del informe del PE sobre la comunicación estratégica de la Unión para contrarrestar la propaganda en su contra por parte de terceros, 2018/2115(INI). Available at: https://www.europarl.europa.eu/doceo/document/TA-8-20190187 ES.html

Flash Eurobarometer 464 (2018). Fake news and disinformation online. April 2018.

Fotyga, A. (2019). Las armas que usan contra nosotros están en continua evolución. 13 marzo 2019. Available at: https://www.europarl.europa.eu/news/es/headlines/euaffairs/20190130STO24604/anna-fotyga-las-armas-que-usan-contra-nosotros-estanen-continua-evolucion 
Freedom House (2020). New disinformation tactics, coronavirus censorship, activist arrests (China Media Bulletin No. 144) Mayo 2020. Available at: https://freedomhouse.org/report/china-media-bulletin/2020/new-disinformationtactics-coronavirus-censorship-activist-arrests

Graham-Harrison, E. (2019). Far-right Facebook groups 'spreading hate to millions in Europe. The Guardian, 22 May 2019.

Hala, M. (2020). A New Invisible Hand Authoritarian Corrosive Capital and the Repurposing of Democracy. National Endowment for Democracy. Available at: https://www.ned.org/wp-content/uploads/2020/03/New-Invisible-Hand-

Authoritarian-Corrosive-Capital-Repurposing-Democracy-Hala.pdf

Lakoff, G. (2017). No pienses en un elefante: Lenguaje y debate político. Editorial: Ediciones Península.

Mallet, V. \& Khalaf, R. (2020, 16 de abril). Interview: Emmanuel Macron says it is time to think the unthinkable. Financial Times. Available at: https://www.ft.com/content/3ea8d790-7fd1-11ea-8fdb-

\section{7ec06edeef84? shareType $=$ nongift}

McCauley, K.N. (2016). Russian influence campaigns against the West. South Carolina. Editor: CreateSpace. Independent Publishing Platform.

Nye, J. (2004). Soft Power: The Means to Success in World Politics. New York: Public Affairs.

Nye, J. (2008). Public Diplomacy and Soft Power. The Annals of the American Academy of Political and Social Science, 616 (1), 94-109.

Nye, J. (2021). Soft power: the evolution of a concept. Journal of Political Power, 14 (1), 196-208.

Recorded Future (2020) Chinese State Media Seeks to Influence International Perceptions of COVID-19 Pandemic. Inksit Group. March 30. Available at:https://www.recordedfuture.com/covid-19-chinese-media-influence/

Roig, C. (2018, 7 de mayo). Las guerras de la era de la desinformación. La Vanguardia.

SEAE (2020a). Special report: disinformation on the coronavirus-short assessment of the information environment. March 19, 2020

SEAE (2020b). Informe especial del SEAE: breve evaluación de las narrativas y la desinformación sobre la pandemia de covid-19/coronavirus (actualizado del 2 al 22 de abril).

SEAE (2020c). EEAAS special report update: short assessment of narratives and disinformation around the covid-19 pandemic (update 23 april - 18 may)

SEAE (2020d). Actualización del informe especial del SEAE: breve evaluación de las narrativas y la desinformación en torno a la pandemia de covid-19 (actualización de mayo a noviembre). 
Tuñón Navarro, J., Oleart, Á., \& Bouza García, L. (2019). Actores Europeos y Desinformación: la disputa entre el factchecking, las agendas alternativas y la geopolítica. Revista De Comunicación, 18(2), 245-260.

Van Ham, P. (2005). Power, Public Diplomacy, and the Pax Americana. In J. Melissen (ed.). The New Public Diplomacy: Soft Power in International Relations. New York: Palgrave Macmillan.

Vilmer J.; Escorcia, A.; Guillaume, M., \& Herrera, J. (2018). Information Manipulation: A Challenge for our Democracies. Resource Centre on Media Freedom in Europe. August 2018. Available at: https://www.rcmediafreedom.eu/Publications/Reports/InformationManipulation-A-Challenge-for-Our-Democracies

Walker, C. (2016). The Authoritarian Threat: The Hijacking of "Soft Power. Journal of Democracy, 27 (1), 49-63.

Walker, C. \& Ludwig, J. (2017). The Meaning of Sharp Power. Foreign Affairs. Available at: https://www.foreignaffairs.com/articles/china/2017-11-16/meaning-sharp-power

Walker, C. (2018). What Is "Sharp Power"? Journal of Democracy, (29) 3, 9-23.

Zhao, X. (2020). How China's State Actors Create a "Us vs US" World during Covid-19 Pandemic on social media. Media and Communication, 8 (2), 452-457. 